\title{
Comparison of Treatment Outcomes After Arthroscopic Repair and Biceps Tenotomy in Patients with Isolated Slap Lesions
}

\section{Özgün Araştırma Research Article}

\author{
SLAP Lezyonlu Hastalarda Artroskopik Onarım ile Biseps \\ Tenotomi Tedavi Sonuçlarının Karşılaştırılması
}

Vahit Yıldız $\odot$

\begin{abstract}
Objective: We compared the clinical outcomes after arthroscopic repair to those after biceps tenotomy in patients with isolated superior labrum anterior posterior (SLAP) Type 2-3 lesions.

Methods: A total of 48 patients with isolated SLAP Type 2-3 lesions, who underwent either arthroscopic repair $(n=024)$ or tenotomy $(n=24)$ were included in the study. CONSTANT shoulder scores in the postoperative 40th month were compared between both groups. Tenotomy was performed for the second time in 6 patients who did not benefit from arthroscopic repair, and their CONSTANT scores estimated before and 12 months after tenotomy were compared.

Results: The clinical outcomes were evaluated in the arthroscopic repair group. Preoperative and postoperative CONSTANT scores were 43.87 (8.32), and 71.41 (9.75) ( $p<0.001)$, respectively. In the tenotomy group pre-, and postoperative CONSTANT scores were 40.25(8.63), and 90.04 (4.04) $(p<0.001)$, respectively. There was not a significant difference between the two groups in terms of the preoperative scores $(p=0.146)$, however, the comparison of the postoperative scores revealed a significant difference $(p<0.001)$. The mean CONSTANT score was 50.3 ( \pm 5.64$)$ at the end of 27 th month, and the mean postoperative CONSTANT score was $86.8( \pm 7.16)$ at the 12th month in six patients whose complaints did not resolve and underwent repeat arthroscopic tenotomy $(p<0.001)$. Conclusion: In our opinion, there is no criterion for repair or tenotomy in isolated SLAP lesions. In these patients, tenotomy may be preferred in the first place because it results in more favourable outcomes compared to repair. The cause of the pain that persists after repair of the SLAP lesion should not be considered as an incorrect, inadequate repair or a complication. In the first place, intolerable biceps tendinitis should be considered.
\end{abstract}

Keywords: SLAP lesion, repair, tenotomy

öz

Amaç: İzole Süperior Labrum Anterior Posterior (SLAP) Tip 2-3 lezyonlu hastalarda artroskopik onarım ile biseps tenotomisinin klinik sonuçlarını karşılaştırmayı amaçladık.

Yöntem: Izole SLAP Tip 2-3 lezyonlu artroskopik onarım (24) ve tenotomi yapılan (24) toplam 48 hasta çalışmaya alınd. Ameliyat sonrası tenotomi ve onarım yapılan hastaların ortalama 40. ayda ki CONSTANT omuz skorları karşılaştırıldı. Onarımdan yarar görmeyen, ikinci kez tekrar opere edilip tenotomi yapılan 6 hastanın 12. ayda onarım sonrası ve tenotomi sonrası CONSTANT skorları karşılaştıııldı.

Bulgular: Klinik sonuçlar değerlendirildiğinde tamir grubunda preoperatif CONSTANT skoru 43,87 (8,32), postoperatif CONSTANT skoru $71,41(9,75)(p<0,001)$ idi. Tenotomi grubunda preoperatif CONSTANT skoru 40,25(8,63), postoperatif CONSTANT skoru 90,04 $(4,04)(p<0,001)$ idi. Preoperatif her iki grup birbirleriyle karşılaştırdığında anlamlı bir fark görülmezken $(p=0,146)$, postoperatif her iki grubun karşılaştırılması anlamlı idi $(p<0,001)$. Ortalama 27. ay sonunda CONSTANT skoru ortalama $50,3( \pm 5,64)$ olup şikayetleri geçmeyen ve tekrar artroskopik tenotomi yapılan altı hastanın 12. ayda postoperatif CONSTANT skoru ortalama 86,8 $( \pm 7,16)$ idi $(p<0,001)$.

Sonuç: Izole SLAP Tip 2-3 lezyonlu olgularda tamir veya tenotomi kararını verdirecek herhangi bir kriter bulunmamaktadır. Bu olgularda onarıma göre daha iyi sonuç verdiği için ilk tercih olarak tenotomi kabul edilebilir. SLAP lezyonu onarımından sonra devam eden ağrının nedeni yanlış, yetersiz onarım ya da komplikasyon olarak kabul edilmemeli, ilk etapta mutlaka tolere edilemeyen biseps tendiniti akla gelmelidir.

Anahtar kelimeler: SLAP Lezyonu, onarım, tenotomi

(C) Telif hakkı TC. Sağlık Bakanlı̆ı İzmir Tepecik Eğit. ve Arastt. Hastanesi. Logos Tip Yayıncluk tarafindan yayınlanmaktadır.

Bu dergide yayınlanan bütün makaleler Creative Commons Atff-GayriTicari 4.0 Uluslararası Lisansı ile lisanslanmıştı.

(c) Copyright Association of Publication of the T.C. Ministry of Health Izmir Tepecik Education and Research Hospital.

This journal published by Logos Medical Publishing.

Licenced by Creative Commons Attribution-NonCommercial 4.0 International (CC BY) 


\section{INTRODUCTION}

The term "superior labrum anterior posterior" lesions in short, the acronym 'SLAP' stands for the detachment of the long head of the biceps tendon at several degrees from its insertion point on the glenoid.

Several modes of physical examination manoeuvers have been described for the identification of SLAP lesions. However, there is not a single test available enabling establishment of a definite diagnosis of a SLAP lesion. Magnetic resonance imaging (MRI) is the most commonly used imaging method for the diagnosis of SLAP lesions (Figure 1A, and Figure 1B).

The recent introduction of arthroscopy into the clinical assessment has made it easier to diagnose SLAP lesions ((Figure 2A). Furthermore, application rates of orthopedic surgeries were found to increase by $55 \%$ between the years 2002 and 2010 while the corresponding increase in arthroscopic repair of the SLAP lesions was found to be $464 \%{ }^{(1)}$.

The conventional surgical treatment of SLAP lesions is to fix the superior labrum to the superior glenoid rim using suture anchors (Figure 2B). Although it is still controversial whether to perform tenotomy and biceps tenodesis for the treatment of SLAP lesions, they are still used as treatment options (Figure 2C).

\section{MATERIALS and METHODS}

The approval of the Ethics Committee of Adnan Menderes University Medical Faculty, with the decision number of 2018/1411, was obtained for the conduct of our study. After informing all eligible patients about the study and its procedures, the consents of the volunteering patients were obtained. The reports of the surgery and videos of 56 patients operated for isolated SLAP lesions between July 2013 and June 2016 were retrospectively reviewed. A total of 48 patients with similar tissue quality and similar type of SLAP lesions, who were at a comparable age and sex distribution and underwent an arthroscopic SLAP repair $(n=24)$ or tenotomy $(n=24)$ were included in the study.

All operations were performed arthroscopically by a single surgeon (VY) while the patient was lying in the beach chair position. The preoperative CONSTANT shoulder scores of the patients were found in the patient charts in the hospital records. CONSTANT shoulder scores of all study patients were recorded at the clinical follow-up visit in the $40^{\text {th }}$ month after the operation and they were compared with the preoperative CONSTANT shoulder scores. The preoperative and postoperative CONSTANT shoulder scores were also compared between the two groups. Six of the 8 patients, who did not benefit from the
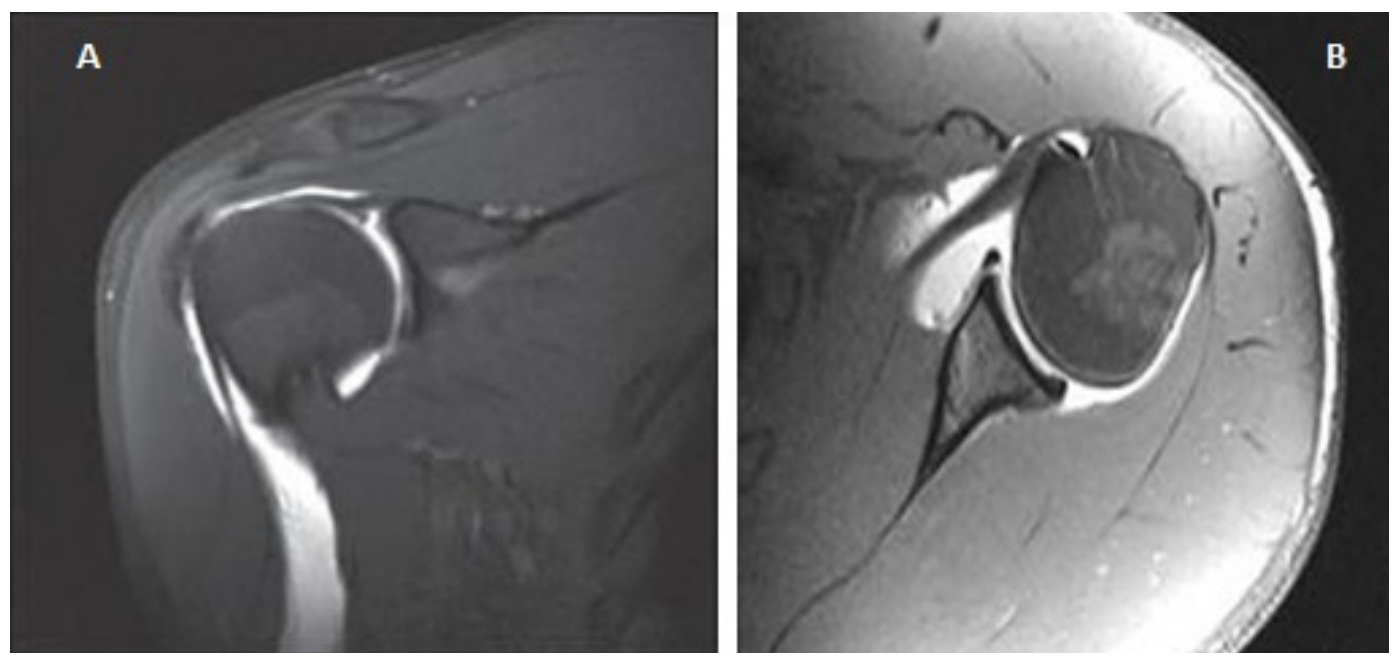

Figure 1. SLAP lesion in the coronal section of MRI (A), SLAP lesion in the axial section of MRI (B). 

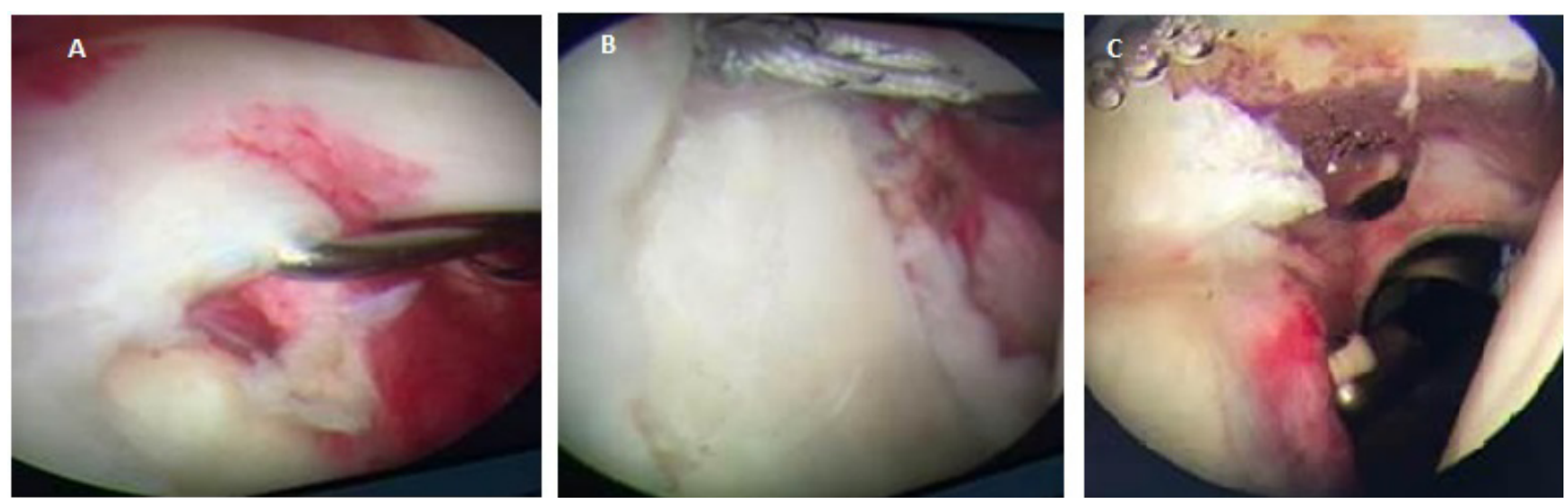

Figure 2. Arthroscopic image of a SLAP lesion (A), Arthroscopic repair of a SLAP lesion (B), Arthroscopic Tenotomy Procedure (C).

arthroscopic repair as observed during the average 27-month follow-up period, were evaluated by MRI and they underwent a revision tenotomy. The CONSTANT shoulder scores of these 6 patients were measured in the 12 month after this tenotomy. Of these 6 patients who underwent the revision surgery, the CONSTANT scores in the $27^{\text {th }}$ month after the repair surgery (after the first operation) and the CONSTANT scores by the 12th month after the tenotomy (after the second operation) were compared.

The Kolmogorov-Smirnov test was used to determine whether the variables conformed to a normal distribution. As all of the variables were found to be normally distributed, descriptive statistics were presented as mean \pm standard deviation. The t-test was used for the comparison of independent groups and the paired samples t-test was used to compare the preoperative and postoperative values.

\section{RESULTS}

The mean age was $55.33(\min 47, \max 59)$ years in the SLAP repair group and 58.66 ( $\min 45, \max 66$ ) years in the tenotomy group. The repair group comprised 19 male and 5 female patients. Tenotomy group consisted of 21 male and 3 female patients. In the repair group, 10 patients had Type 2, and 9 patients Type 3 lesions, while 5 patients had indeterminate Type 2 or 3 SLAP lesions. In the tenotomy group, 8 patients had Type 2, 11 patients Type 3 lesions, and 5 patients indeterminate Type 2 or 3 SLAP lesions. The mean duration of operation was 56.40 minutes ( $\min 36, \max 98$ ) in the repair group and approximately 32.33 minutes ( $\min 23$, max 66) in the tenotomy group. The mean length of hospital stay was 1.40 days ( $\min 1, \max 4)$ in the repair group and 1.25 days $(\min 1, \max 3$ ) in the tenotomy group. There was no significant difference between the two groups in terms of age, gender, SLAP lesion type, operation time and length of stay (Table 1).

In the SLAP repair group, the pre-, and postoperative CONSTANT scores were 43.87 (8.32) and 71.41 (9.75), respectively $(p<0.001)$. In the tenotomy group, the pre-, and postoperative CONSTANT scores were 40.25 (8.63) and 90.04 (4.04), respectively $(p<0.001)$. There was not a significant difference between preoperative scores of two groups $(p=0.146)$, however, the postoperative comparison revealed a significant difference $(p<0.001)$ (Table 2).

Of the six patients who did not benefit from the arthroscopic repair and underwent revision surgery, the mean CONSTANT shoulder scores before, and after tenotomy were 50.3 ( \pm 5.64 ) and $86.8( \pm 7.16)$, respectively. The comparison of the CONSTANT shoulder scores before and after tenotomy revealed a significant difference $(p<0.001)$ (Table 3$)$. 
Table 1. Distribution and comparison of the patients.

\begin{tabular}{|c|c|c|c|c|c|c|}
\hline & Number of Patients & Age (Mean Age) & Gender & Type of the SLAP lesion & $\begin{array}{c}\text { Duration of Operation } \\
\text { (minutes) }\end{array}$ & $\begin{array}{l}\text { Length of Hospital Stay } \\
\text { (days) }\end{array}$ \\
\hline Repair & 24 & $\begin{array}{l}55.33(\min 47 \\
\max 59)\end{array}$ & $\begin{array}{l}19 \text { Male, } \\
5 \text { Female }\end{array}$ & $\begin{array}{c}10, \text { Type } 2 \\
9 \text {, Type } 3 \\
5, \text { Type } 2-3\end{array}$ & $56.40(\min 36, \max 98)$ & $1.40(\min 1, \max 4)$ \\
\hline Tenotomy & 24 & $\begin{array}{l}58.66(\min 45 \\
\max 66)\end{array}$ & $\begin{array}{l}21 \text { Male, } \\
3 \text { Female }\end{array}$ & $\begin{array}{c}8, \text { Type } 2 \\
11 \text {, Type } 3 \\
5 \text {, Type } 2-3\end{array}$ & $32.33(\min 23, \max 66)$ & $1.25(\min 1, \max 3)$ \\
\hline$p$ & & 0,125 & 0,308 & 0,109 & 0,082 & 0,136 \\
\hline
\end{tabular}

Table 2. Comparison of the repair and tenotomy groups.

\begin{tabular}{lcccc}
\hline & Number of Patients & Preoperative Constant Score & Postoperative Constant Score & $p$ \\
\hline Repair & 24 & $43.87( \pm 8.32)$ & $71.41( \pm 9.75)$ & $<0.001$ \\
\hline Tenotomy & 24 & $40.25( \pm 8.63)$ & $90.04( \pm 4.04)$ & $<0.001$ \\
\hline$p$ & & 0.146 & 0.001 \\
\hline
\end{tabular}

Table 3. Comparison of CONSTANT scores before and after tenotomy in the revision surgery patients.

\begin{tabular}{lcccc}
\hline & Number of Patients & CONSTANT score after the repair & CONSTANT score after the tenotomy & $\mathbf{p}$ \\
\hline Tenotomy patients after the repair & 6 & $50.3( \pm 5.64)$ & $86.8( \pm 7.16)$ & $<0.001$ \\
\hline
\end{tabular}

Extravasation was observed during the operation in 7 patients in the repair group and in 3 patients in the tenotomy group. One patient in the repair group developed transient neuropraxia lasting about 2 months. In three patients who underwent tenotomy, a cosmetic problem due to the swelling caused by the retracted biceps muscle was observed in the forearm, however, no interventions were performed.

\section{DISCUSSION}

The SLAP lesions were first reported in overheadthrowing athletes by Andrews in $1985^{(2)}$. In 1990, Snyder described the SLAP lesions for the first time as the anterior-posterior detachment of the superior labrum and the long head of the biceps from the insertion point on the glenoid and made the first classification ${ }^{(3)}$. In 1995, Maffet et al. ${ }^{(7)}$ reported 3 additional types for SLAP tears. Currently, 10 different types of SLAP tears are recognized ${ }^{(4)}$.

There are studies available in the literature, indicating that the biomechanics of the biceps-labrum complex is accountable for the development of SLAP lesions. Pagnani et al. demonstrated that the stabilization problems in the biceps insertion lead to impaired anterior-posterior and superior-inferior types of stability in the glenohumeral joint ${ }^{(5)}$. Another study demonstrated that the long head of the biceps stabilized the humeral head in the glenoid during the abduction, reporting that it played an important role in the shoulder stability ${ }^{(6)}$. It was reported that SLAP 2 lesions were one of the causes of the glenohumeral instability and that arthroscopic repair of the SLAP Type 2 lesions restored the stability ${ }^{(7)}$. Rodosky reported that the biceps-labrum complex resists the torsion during the external rotation of the shoulder 
in the abduction position, supporting the anterior stability ${ }^{(8)}$.

O'Brien and Speed tests are used especially in making the diagnosis of SLAP lesions. In his study, Ben Kibler reported that the newly introduced dynamic shear test was promising for the diagnosis of SLAP lesions ${ }^{\left({ }^{9}\right)}$. In contrast, Cook et al. argued that the dynamic shear testing is not clinically useful in diagnosing SLAP lesions ${ }^{(10)}$.

Several studies identified accompanying pathologies in $70 \%$ of the patients with SLAP lesions. Various incidence rates have been reported for comorbidities including rotator cuff tears (40\%), anterior instability (15\%), chondral pathology in the humeral head occurred (15\%), and arthritis in the acromioclavicular joint $(11 \%)^{(11)}$. We did not find any studies in the literature including only the patients with isolated type 2-3 SLAP lesions as we did in this present study.

Conventional surgical treatment of SLAP lesions is known as fixing the superior labrum to the superior glenoid using suture anchors, The results of the preliminary studies demonstrated that the outcomes after this intervention was successful in terms of alleviating the pain and restoring physical functioning in sports ${ }^{(12-16)}$.

In time, it has been recognized that the outcomes of SLAP repair interventions were not as good as they were reported in previous studies, leading the surgeons to prefer tenotomy or tenodesis as another treatment option. Boileau et al. compared the outcomes of 15 patients who underwent biceps tenodesis with the outcomes of 10 patients who underwent repairs for the treatment of Type 2 SLAP lesions. They reported relatively higher satisfaction rate in the tenodesis group (87\%) compared to the repair group (40\%). In that study, the authors observed that the proportion of the patients returning to their sportive activities was higher in the tenodesis group (87\%) compared to that in the SLAP repair group $(20 \%)^{(17)}$. Denard and Weber reported similar results in their study, too ${ }^{(18,19)}$.
Repair of SLAP lesions is usually recommended in individuals engaged in sports with overhead-throwing activities (21), whereas tenodesis or tenotomy are recommended for older patients with accompanying pathologies as treatment options. Huri et al. conducted a review of the literature on the treatment of SLAP lesions and reported that tenotomy should be performed in the patients with rotator cuff tears, however, they also reported that the role of tenotomy was controversial in overhead-throwing athletes. Again, in this study, the authors stated that age was an important factor and they suggested that, instead of SLAP repair, tenotomy or tenodesis should be performed in patients over 40 years of age ${ }^{(20)}$.

A literature review revealed that studies included only patients undergoing tenotomies or repairs. This present study not only compared the outcomes of tenotomy or repair surgeries, but it also included the evaluation of the outcomes of the patients undergoing a revision tenotomy after a repair. MRI was performed by the $12^{\text {th }}$ month in the follow-up period in 8 patients who did not benefit from arthroscopic repair. Fluid collection in the bicipital groove and increased effusion in the joint were observed in all of these patients. A revision tenotomy was performed arthroscopically in six out of these eight patients. A review of the charts of these patients along with the latest surgery reports and videos revealed that all of them developed biceps tendinitis. In addition, there was a deformation of the sutured tissue in two patients and the biceps tendon was partially strained in one patient. Suture laxity was not observed in any of the patients. Although the repair process is sufficient and accomplished properly, the persistent pain may indicate intolerable biceps tendinitis, which may result from the retraction of the biceps tendon in time or it may develop due to tight suturing or suture laxity more than it is required.

Based on the results of this study, it can be argued that the cause of the persisting pain after the repair of SLAP lesions should not be considered to be due to an inadequate or insufficient repair or due to a developing complication; and intolerable biceps 
tendinitis should be kept in mind.

\section{CONCLUSION}

At the time of conducting our study, no clear criteria were available to make a decision to perform a repair in the patients with isolated Type 2-3 SLAP lesions. Based on the results of our study, it was determined that tenotomy resulted in favourable outcomes in all cases. Therefore, in patients with isolated indeterminate type 2-3 SLAP lesions, tenotomy should be preferred rather than a repair. We are of the opinion that tenotomy can conveniently be performed in young patients with isolated SLAP lesions, in contrast to the theory that tenotomy can only be performed in elderly patients having a poor tissue quality with other comorbid pathologies.

According to this present study, the cause of persisting pain after the repair of SLAP lesions should not only be considered to occur due to improper or insufficient repair procedures or complications but intolerable symptoms of biceps tendinitis should definitely be included in the differential diagnosis as well.

Ethics Committee Approval: Approval was obtained from Adnan Menderes University Faculty of Medicine Non-Invasive Clinical Research Ethics Committee (2018/1411).

Conflict of Interest: There is no conflict of interest. Funding: None.

Informed Consent: None.

\section{REFERENCES}

1. Onyekwelu I, Khatib O, Zuckerman JD, Rokito AS, Kwon YW. The rising incidence of arthroscopic superior labrum anterior and posterior (SLAP) repairs. J Shoulder Elbow Surg. 2012 Jun;21(6):728-31. [CrossRef]

2. Andrews JR, Carson WG Jr., McLeod WD. Glenoid labrum tears related to the long head of the biceps. Am J Sports Med. 1985 Sep-Oct;13(5):337-41. [CrossRef]

3. Snyder SJ, Karzel RP, Del Pizzo W, Ferkel RD, Friedman MJ. SLAP lesions of the shoulder. Arthroscopy. 1990;6(4):274-9. [CrossRef]

4. Modarresi S, Motamedi D, Jude CM. Superior labral anteroposterior lesions of the shoulder: part 2, mechanisms and classification. AJR Am J Roentgenol. 2011 Sep;197(3):60411. [CrossRef]
5. Pagnani MJ, Deng XH, Warren RF, Torzilli PA, Altchek DW. Effect of lesions of the superior portion of the glenoid labrum on glenohumeral translation. J Bone Joint Surg Am. 1995 Jul;77(7):1003-10. [CrossRef]

6. Warner JJ, McMahon PJ. The role of the long head of the biceps brachii in superior stability of the glenohumeral joint. J Bone Joint Surg Am. 1995 Mar;77(3):366-72. [CrossRef]

7. Panossian VR, Mihata T, Tibone JE, Fitzpatrick MJ, McGarry $\mathrm{MH}$, Lee TQ. Biomechanical analysis of isolated type II SLAP lesions and repair. J Shoulder Elbow Surg. 2005 SepOct;14(5):529-34. [CrossRef]

8. Rodosky MW, Harner CD, Fu FH. The role of the long head of the biceps muscle and superior glenoid labrum in anterior stability of the shoulder. Am J Sports Med. 1994 JanFeb;22(1):121-30. [CrossRef]

9. Ben Kibler W, Sciascia AD, Hester P, Dome D, Jacobs C. Clinical utility of traditional and new tests in the diagnosis of biceps tendon injuries and superior labrum anterior and posterior lesions in the shoulder. Am J Sports Med. 2009 Sep;37(9):1840-7. [CrossRef]

10. Cook C, Beaty S, Kissenberth MJ, Siffri P, Pill SG, Hawkins RJ. Diagnostic accuracy of five orthopedic clinical tests for diagnosis of superior labrum anterior posterior (SLAP) lesions. J Shoulder Elbow Surg. 2012 Jan;21(1):13-22. [CrossRef]

11. Nam EK, Snyder SJ. The diagnosis and treatment of superior labrum, anterior and posterior (SLAP) lesions. Am J Sports Med. 2003 Sep-Oct;31(5):798-810. [CrossRef]

12. Schroder CP, Skare $O$, Gjengedal E, Uppheim G, Reikerås $O$, Brox JI. Long-term results after SLAP repair: a 5-year follow up study of 107 patients with comparison of patients aged over and under 40 years. Arthroscopy. 2012 Nov;28(11):1601-7. [CrossRef]

13. Kanatli U, Ozturk BY, Bolukbasi S. Arthroscopic repair of type II superior labrum anterior posterior (SLAP) lesions in patients over the age of 45 years: a prospective study. Arch Orthop Trauma Surg. 2011 Aug;131(8):1107-13. [CrossRef]

14. Ide J, Maeda S, Takagi K. Sports activity after arthroscopic superior labral repair using suture anchors in overhead throwing athletes. Am J Sports Med. 2005 Apr;33(4):507-14. [CrossRef]

15. Neri BR, El Attrache NS, Owsley KC, Mohr K, Yocum LA. Outcome of type II superior labral anterior posterior repairs in elite overhead athletes: Effect of concomitant partialthickness rotator cuff tears. Am J Sports Med. 2011 Jan;39(1):114-20. [CrossRef]

16. Brockmeier SF, Voos JE, Williams RJ 3rd, Altchek DW, Cordasco FA, Allen AA. Outcomes after arthroscopic repair of type-II SLAP lesions. J Bone Joint Surg Am. 2009 Jul;91(7):1595603. [CrossRef]

17. Boileau P, Parratte S, Chuinard C, Roussanne Y, Shia D, Bicknell R. Arthroscopic treatment of isolated type II SLAP lesions: biceps tenodesis as an alternative to reinsertion. Am J Sports Med. 2009 May;37(5):929-36. [CrossRef]

18. Denard PJ, Lädermann A, Burkhart SS. Long-term outcome after arthroscopic repair of type II SLAP lesions: results according to age and workers' compensation status. Arthroscopy. 2012 Apr;28(4):451-7. [CrossRef]

19. Weber SC. Surgical management of the failed SLAP repair. Sports Med Arthrosc Rev. 2010 Sep;18(3):162-6. [CrossRef]

20. Huri G, Hyun YS, Garbis NG, McFarland EG. Treatment of superior labrum anterior posterior lesions: a literature review. Acta Orthop Traumatol Turc. 2014;48(3):290-7. [CrossRef] 